IMAGE AND REPRESENTATION 


\section{IMAGE AND REPRESENTATION}

Key Concepts in Media Studies

Nick Lacey

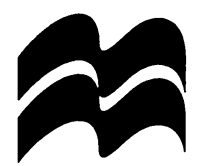


All rights reserved. No reproduction, copy or transmission of this publication may be made without written permission.

No paragraph of this publication may be reproduced, copied or transmitted save with written permission or in accordance with the provisions of the Copyright, Designs and Patents Act 1988, or under the terms of any licence permitting limited copying issued by the Copyright Licensing Agency, 90 Tottenham Court Road, London W1P 9HE.

Any person who does any unauthorised act in relation to this publication may be liable to criminal prosecution and civil claims for damages.

The author has asserted his right to be identified as the author of this work in accordance with the Copyright, Designs and Patents Act 1988.

First published 1998 by

MACMILLAN PRESS LTD

Houndmills, Basingstoke, Hampshire RG21 6XS and London

Companies and representatives throughout the world

ISBN 978-0-333-64436-2

DOI 10.1007/978-1-349-26712-5

A catalogue record for this book is available from the British Library.

$\begin{array}{llllllllll}10 & 9 & 8 & 7 & 6 & 5 & 4 & 3 & 2 & 1\end{array}$

$\begin{array}{llllllllll}07 & 06 & 05 & 04 & 03 & 02 & 01 & 00 & 99 & 98\end{array}$

Copy-edited and typeset by Povey-Edmondson

Tavistock and Rochdale, England

Published in the United States of America 1998 by

ST. MARTIN'S PRESS, INC.,

Scholarly and Reference Division,

175 Fifth Avenue, New York, N.Y. 10010

ISBN 978-0-312-21202-5 clothbound

ISBN 978-0-312-21203-2 paperback 
To Kirsten 


\section{CONTENTS}

Acknowledgements ix

Introduction $\quad 1$

1 Introduction to Image Analysis 5

1.1 'Seeing is believing' 5

1.2 Speech as communication 6

1.3 Interpreting the world around us $\quad 8$

1.4 Non-verbal communication (NVC) 11

1.5 Image analysis 14

1.6 Form 14

1.7 Content (mise-en-scène) 20

1.8 What does it all mean? 22

1.9 Context, contact, and the message 27

1.10 Codes 31

1.11 Colour 38

1.12 Analysis of advertisement: Nokia 232

1.13 Images in sequence 46

1.14 Sound 52

1.15 Storyboarding 54

2 Semiotics 56

2.1 Introduction to semiotics 56

2.2 Saussure 56

2.3 C.S. Peirce 65

2.4 Barthes 67

2.5 Binary oppositions 69

2.6 Semiotic analysis: Nokia 232 advertisement 70

3 Jakobson's Model Revisited 76

3.1 Introduction 76

3.2 Jakobson's model revisited 76

4 Advanced Image Analysis $\quad 82$

4.1 Introduction $\quad 82$

4.2 High culture versus low culture 84

4.3 Authorial intent 86 
4.4 'Preferred' reading $\quad 87$

4.5 Polysemy 90

4.6 Intrapersonal communication 95

4.7 Ideology 98

$\begin{array}{llr}4.8 & \text { Discourse } & 105\end{array}$

4.9 Hegemony 112

4.10 Alternative systems of editing 114

$\begin{array}{ll}4.11 \text { Counter cinema } & 117\end{array}$

4.12 A history of Western images 123

5 Representation $\quad 131$

5.1 Introduction 131

5.2 Dyer's typography 131

5.3 Re-presentation 132

5.4 Types and stereotypes 133

5.5 Who does the re-presenting? 143

5.6 Audience and representation 144

5.7 Institutional case study: British television news 148

5.8 Institutional case study: More! 159

5.9 Generic case study: the Western 163

5.10 Film case study: Blue Steel 167

5.11 Photographic case study: Cindy Sherman 172

5.12 Propaganda 175

6 Representation and Reality 189

6.1 A history of realism 189

6.2 Realism and narrative cinema 195

6.3 The Jungle and St Joan of the Stockyards 198

6.4 Formal realism in documentary 201

6.5 Documentaries and reality 208

6.6 May 1968 and theories of representation 212

7 Technology 221

7.1 Image and Representation 222

Appendix 1: Storyboarding 228

Appendix 2: Analysis of Unseen Text 242

Telegraph \& Argus 242

Nokia 232

Bibliography 247

Index 252 


\section{ACKNOWLEDGEMENTS}

The author wishes to thank the following people without whom etc.: Kevin Atkins who made sure everything, more or less, made sense; Richard Duckworth who showed me that some of it didn't make sense and how it could make (some) sense; Henrik Bicat who made the computer make sense of something that shouldn't have; Carla Graham and Merle Bentley for the Blade Runner sketches; Alex and Kate for not turning my PC off at crucial moments; my longsuffering wife who entertained the kids on the promise of riches when this was finished; my mum for having me; my students for 'test-driving' the material and no you can't have any of the royalties; my mother-in-law for helping my wife tame my animals; Roy Stafford for letting me use the 'in the picture' spread and his enthusiasm for the subject; Len Masterman for his exceptionally useful comments; Keith Povey and Eileen Ashcroft for their editing and excellent suggestions; Everton FC for not being relegated and winning the Cup; Brian Bicat for talking Brecht; Dave Croft for being Dave Croft; Catherine Gray, Frances Arnold, Jo Digby and Nancy Williams at Macmillan.

Nick LaceY

The author and publishers would like to thank the following for permission to reproduce copyright material: Barnaby's Picture Library for 'Mother and Child Cooking' by L. Howling; Emap Elan Ltd for the front cover of More!, March 1995; Alison Brolls and Nicole Perez at Greycom Ltd for the Nokia 'Little Black Number' advertisement and its schedule; James Brown at IPC Magazines for the front cover of Loaded, November 1996; Columbia Pictures Corporation for film stills from Gilda and The Wild One, courtesy of The Kobal Collection; MGM/Pathe for the film still from Thelma and Louise, courtesy of The Kobal collection; the artist and Metro 
Pictures for 'Untitled Film Still No. 21' by Cindy Sherman; Richard Smith/Katz Pictures for 'West End Shopper Argues with a Protester'; Roy Stafford for the centre-page spread of In the Picture from the Summer 1993 issue; Perry Austin-Clark of the Telegraph $\mathcal{E}$ Argus for the front page of the 2 December 1994 issue; Vestron/MGM/ United Artists for the film still from Blue Steel, courtesy of The Kobal Collection. Every effort has been made to trace all the copyrightholders, but if any have been inadvertently overlooked the publishers will be pleased to make the necessary arrangement at the first opportunity. 